\title{
An in vitro Comparison of Bond Strength of Different Sealers/Obturation Systems to Root Dentin Using the Push-Out Test at 2 Weeks and 3 Months after Obturation
}

\author{
Wai Ying Yap ${ }^{a}$ Zeti Adura Che Ab Aziz ${ }^{a} \quad$ Noor Hayati Azamia \\ Afaf Yahya Al-Haddad ${ }^{\mathrm{b}}$ Asfand Ali Khan $^{\mathrm{a}}$ \\ ${ }^{a}$ Department of Restorative Dentistry, Faculty of Dentistry, University of Malaya, Kuala Lumpur, and ${ }^{b}$ Department of \\ Dental Materials and Equipment, Faculty of Dentistry, Mahsa University, Selangor, Malaysia
}

\section{Significance of the Study}

- In this study, the push-out bond strength of the TotalFill $\mathrm{BC}^{\mathrm{TM}}$ sealer was comparable to AH Plus ${ }^{\circledR}$ but higher than the EndoREZ ${ }^{\circledR}$ sealer. It increased over time $(1.74 \pm 0.43$ and $3.69 \pm 1.20 \mathrm{MPa}$ at 2 weeks and 3 months after obturation, respectively). Hence, a bioceramic sealer could be a good material of choice for obturation.

\section{Keywords}

Bioceramic sealer · Bond strength $\cdot$ EndoREZ ${ }^{\circledR} \cdot$ Push-out test $\cdot$ TotalFill BC ${ }^{\mathrm{TM}}$

\begin{abstract}
Objective: To evaluate the push-out bond strength and failure modes of different sealers/obturation systems to intraradicular dentin at 2 weeks and 3 months after obturation compared to AH Plus ${ }^{\circledR} /$ gutta-percha. Materials and Methods: A total of 180 root slices from 60 single-canal anterior teeth were prepared and assigned to 5 experimental groups ( $n=36$ in each group), designated as G1 (AH Plus ${ }^{\circledR} /$ guttapercha), G2 (TotalFill BC'M sealer/BC-coated gutta-percha), G3 (TotalFill BCTM sealer/gutta-percha), G4 (EndoREZ ${ }^{\circledR}$ sealer/EndoREZ ${ }^{\circledR}$-coated gutta-percha), and G5 (EndoREZ ${ }^{\circledR}$ sealer/gutta-percha). Push-out bond strengths of 18 root slices in each group were assessed at 2 weeks and the other 18 at 3 months after obturation using a universal testing machine.
\end{abstract}

\section{KARGER}

E-Mail karger@karger.com www.karger.com/mpp
This is an Open Access article licensed under the Creative Common Attribution-NonCommercial-4.0 International License (CC BY-NC) (http://www.karger.com/Services/OpenAccessLicense), applicable to the online version of the article only. Usage and distribution for commercial purposes requires written permission.
Data were analyzed using repeated measures ANOVA. An independent $t$ test was used to compare the mean push-out bond strength for each group at 2 weeks and 3 months after obturation. Results: The mean push-out bond strengths of G4 and G5 were significantly lower than those of G1, G2, and G3 $(p<0.05)$ at both 2 weeks (G1: $1.46 \pm 0.29$ MPa, G2: $1.74 \pm 0.43 \mathrm{MPa}, \mathrm{G} 3: 1.74 \pm 0.43 \mathrm{MPa}, \mathrm{G} 4: 0.66 \pm 0.31 \mathrm{MPa}, \mathrm{G} 5$ : $0.74 \pm 0.47 \mathrm{MPa}$ ) and 3 months after obturation (G1: $1.70 \pm$ $1.05 \mathrm{MPa}, \mathrm{G} 2: 3.69 \pm 1.20 \mathrm{MPa}, \mathrm{G} 3: 2.84 \pm 0.83 \mathrm{MPa}, \mathrm{G} 4$ : $0.14 \pm 0.05 \mathrm{MPa}, \mathrm{G} 5: 0.24 \pm 0.10 \mathrm{MPa})$. The mean push-out bond strengths of $\mathrm{G} 2(3.69 \pm 1.20 \mathrm{MPa})$ and $\mathrm{G} 3(2.84 \pm 0.83$ $\mathrm{MPa}$ ) were higher at 3 months compared to 2 weeks after obturation (G2: $1.74 \pm 0.43 \mathrm{MPa}, \mathrm{G} 3: 1.33 \pm 0.29 \mathrm{MPa}$ ). Conclusion: The TotalFill BCTM obturation system (G2) and the TotalFill BCTM sealer/gutta-percha (G3) showed comparable bond strength to $\mathrm{AH}$ Plus ${ }^{\circledR}$. Their bond strength increased over time, whereas the EndoREZ ${ }^{\circledR}$ obturation system (G4) and EndoREZ sealer (G5) had low push-out bond strength which decreased over time.

(C) 2017 The Author(s) Published by S. Karger AG, Basel

Wai Ying Yap

Department of Restorative Dentistry, Faculty of Dentistry, University of Malaya Jalan Universiti

50603 Kuala Lumpur (Malaysia)

E-Mail wying1128@ hotmail.com 


\section{Introduction}

Three-dimensional obturation that completely seals the entire root canal system from any bacterial ingress from oral cavity and periradicular tissues is important for successful endodontic treatment [1]. One of the desirable properties of the root canal filling is its ability to adhere to radicular dentin [2]. Good adhesion eliminates percolation of fluids between the filling and the root canal wall [3], and resists dislodgement of fillings during subsequent manipulation, e.g., postspace preparation [4]. In the early 2000s, manufacturers had further incorporated adhesive dentistry into endodontics by introducing obturation systems with emphasis on obtaining a "monoblock" in which a single cohesive unit is formed through bonding of the core material, sealing agent, and root canal dentin [5]. Examples of such systems include Resilon (Pentron Clinical Technologies, Wallingford, UK), Activ GP (Brasseler, Savannah, GA, USA), EndoREZ ${ }^{\circledR}$ (Ultradent, South Jordan, UT, USA) and the latest TotalFill BC $^{\text {TM }}$ (FKG Dentaire, La Chaux-de-Fonds, Switzerland).

The EndoREZ ${ }^{\circledR}$ system consists of a urethane dimethacrylate-based self-priming sealer and a polybutadiene-diisocyanate-methacrylate resin-coated gutta-percha (GP) core material. It is hydrophilic and has an affinity for moisture present deep in dentinal tubules and lateral canals [6].

The TotalFill $\mathrm{BC}^{\mathrm{TM}}$ obturation system contains bioceramic nanoparticles impregnated in TotalFill $\mathrm{BC}^{\mathrm{TM}}$ points and $\mathrm{BC}$ sealer that utilizes the moisture naturally present in dentinal tubules to initiate its setting reaction [7]. The BC sealer is biocompatible and osteogenic, and exhibits zero shrinkage [8]. According to the manufacturer, a gap-free obturation is achieved when the bioceramic particles found in the BC sealer are used in conjunction with the bioceramic particles in $\mathrm{BC}$ points.

AH Plus ${ }^{\circledR}$ (Dentsply Maillefer, Ballaigues, Switzerland) is a 2-component paste/paste root canal sealer based on epoxy-amine resin. It has an extensive market history. Furthermore, it has always been used as a reference and standard in many investigations [8-11]. The chemical composition of EndoREZ ${ }^{\circledR}$, TotalFill $\mathrm{BC}^{\mathrm{TM}}$, and $\mathrm{AH}$ Plus ${ }^{\circledR}$ is summarized in Table 1.

Resistance to dislodging force by root filling materials during function is highly desirable. The push-out test is widely used to assess the bond strength at the root canal filling/dentin interface [12]. The push-out test produces a more homogeneous stress distribution and less variability than the microtensile bond test [13]. It yields repetitive results and does not need highly sophisticated equipment [8].
Table 1. Chemical composition of EndoREZ ${ }^{\circledR}$, TotalFill BC ${ }^{\mathrm{TM}}$, and AH Plus ${ }^{\circledR}$

\begin{tabular}{lll}
\hline Sealers & Type of sealer & Chemical composition \\
\hline EndoREZ $^{\circledR}$ & $\begin{array}{l}\text { Methacrylate } \\
\text { resin based }\end{array}$ & $\begin{array}{l}\text { Bismuth compound, urethane } \\
\text { dimethacrylate, triethylene glycol } \\
\text { dimethacrylate, peroxide initiator }\end{array}$ \\
\hline $\begin{array}{l}\text { TotalFill } \\
\text { BC }^{\mathrm{TM}}\end{array}$ & $\begin{array}{l}\text { Calcium } \\
\text { silicate based }\end{array}$ & $\begin{array}{l}\text { Zirconium oxide, calcium } \\
\text { silicates, calcium phosphate, } \\
\text { calcium hydroxide, filler, } \\
\text { thickening agents }\end{array}$ \\
\hline AH Plus $^{\circledR}$ & $\begin{array}{l}\text { Epoxy resin } \\
\text { based }\end{array}$ & $\begin{array}{l}\text { Epoxy resins, zirconium oxide, } \\
\text { iron oxide, calcium tungstate, } \\
\text { silicone oil }\end{array}$ \\
\hline
\end{tabular}

Degradation of the resin bond in restorative applications has been shown to be due to the functional forces and unpolymerized resin [14]. An interfacial gap is always present in resin-bonded restorations, be it in restorative dentistry or bonded obturating materials, and this gap formation increases with time [14]. Loss of bond strength was first detected in the laboratory at 3 months [14]. To date, no bond strength test has been reported at 3 months after obturation. Therefore, the objective of this study was to evaluate the push-out bond strength of different obturation systems (TotalFill $\mathrm{BC}^{\mathrm{TM}}$ obturation system: TotalFill BC ${ }^{\mathrm{TM}}$ sealer/BC-coated GP, TotalFill BC ${ }^{\mathrm{TM}}$ sealer with GP; EndoREZ ${ }^{\circledR}$ obturation system: EndoREZ $^{\circledR}$ sealer/EndoREZ ${ }^{\circledR}$-coated GP, EndoREZ ${ }^{\circledR}$ sealer with GP) to intraradicular dentin at 2 weeks and 3 months after obturation compared to AH Plus ${ }^{\circledR}$ with GP.

\section{Materials and Methods}

\section{Specimen Preparation}

Sample size calculation was done using the Power and Sample Size calculation program (Vanderbilt Biostatistics, Nashville, TN, USA). The estimated power was 0.80 and the significance level was set at $\alpha=0.05$. A minimum of 5 teeth per group were needed for this study to reject the null hypothesis.

Sixty extracted maxillary central incisors were selected. Exclusion criteria were caries, curved roots, open apices, cracks, or previous root canal treatments. A radiograph was taken for each tooth sample to ensure no intracanal abnormality (e.g., sclerosed canal, root resorption) was present. The teeth were disinfected in $0.5 \%$ chloramines $\mathrm{T}$ trihydrate solution and stored in distilled water until use. The teeth were decoronated to obtain approximately 16-mm-long root segments. Canal patency was achieved using $\mathrm{K}$-file size \# 10. The first bind file for each root was determined, and those with a first bind file equal or smaller than K-file size \#25 were included in the study. Working length was established by placing 

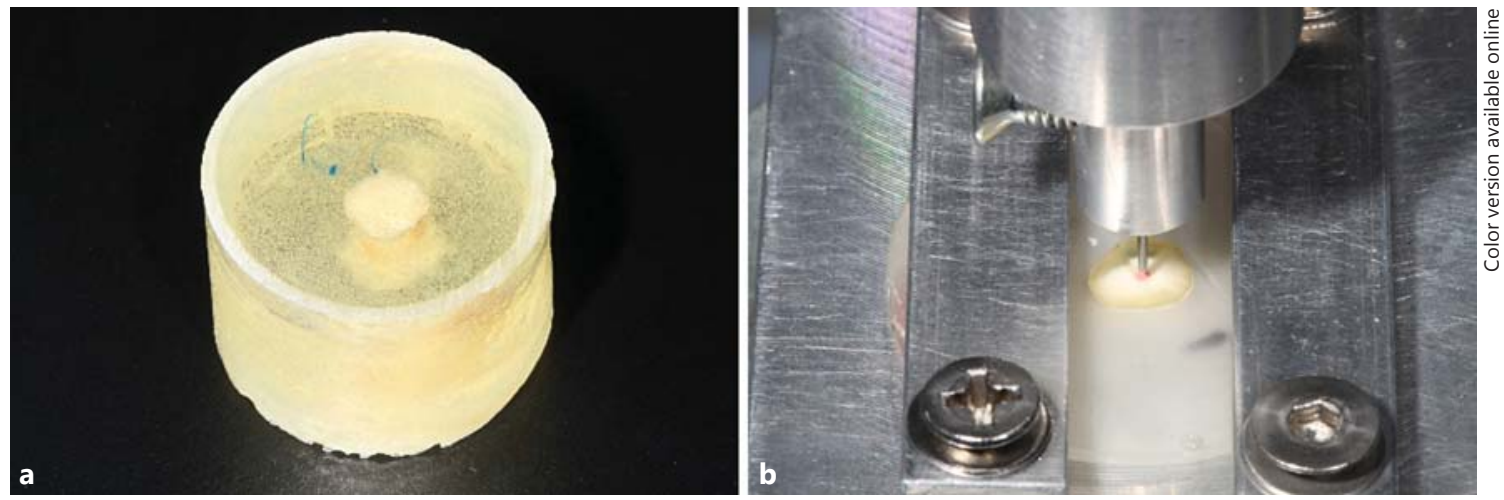

Fig. 1. a Root embedded in epoxy resin. b Positioning of the root slice on the jig.

a stainless steel K-file size \#10 into the canal until the tip of the file was visible at the apical foramen and then subtracting $1 \mathrm{~mm}$. Cleaning and shaping were done using ProTaper Universal (Dentsply Maillefer) in a modified crown-down manner according to the manufacturer's instructions using a gentle in-and-out motion up to size F4 (\#40/0.06).

Canals were passively irrigated with $5 \mathrm{ml}$ of $5.25 \%$ sodium hypochlorite solution between each instrument using a $31-\mathrm{G}$ NaviTip (Ultradent, South Jordan, UT, USA) double-side port irrigation needle with a conventional syringe at $1 \mathrm{~mm}$ short from the working length. At the end of the procedure, $5 \mathrm{ml}$ of $17 \%$ EDTA solution (SmearClear; SynbronEndo, Orange, CA, USA) was used for irrigation for $1 \mathrm{~min}$, followed by $5 \mathrm{ml}$ of $5.25 \%$ sodium hypochlorite and a final rinse with copious amounts of distilled water. The roots were then divided randomly into 5 groups with 12 roots per group based on the obturation systems tested.

\section{Obturation}

Group 1 (AH Plus $\left.{ }^{\circledR} / \mathrm{GP}\right)$ : AH Plus ${ }^{\circledR}$ sealer was mixed on a paper pad and applied to the root canal walls using a lentulo spiral size 3 (Dentsply Maillefer) at $100 \mathrm{rpm}$. A \#40/0.06 taper GP cone (ProTaper GP F4; Dentsply Maillefer) was coated with AH Plus ${ }^{\circledR}$ sealer and pumped a few times in the root canal. The cone was removed, recoated with sealer, and then inserted up to the working length. Group 2 (TotalFill BC BM $^{\mathrm{TM}}$ obturation system - TotalFill $\mathrm{BC}^{\mathrm{TM}}$ sealer/BC-coated GP): TotalFill $\mathrm{BC}^{\mathrm{TM}}$ sealer was syringed into the canal and then a \#40/0.06 taper TotalFill $\mathrm{BC}^{\mathrm{TM}}$ cone was placed in the canal up to working length. Group 3 (TotalFill BC ${ }^{\mathrm{TM}}$ sealer/GP): TotalFill $\mathrm{BC}^{\mathrm{TM}}$ sealer was syringed into the canal and then a \#40/0.06 taper GP was placed in the canal up to working length. Group 4 (EndoREZ ${ }^{\circledR}$ obturation system - EndoREZ ${ }^{\circledR}$ sealer/EndoREZ ${ }^{\circledR}$-coated GP): EndoREZ ${ }^{\circledR}$ sealer was syringed into the canal and then a \#40/0.06 taper EndoREZ ${ }^{\circledR}$ cone was placed in the canal up to working length. Group 5 (EndoREZ ${ }^{\circledR}$ sealer/GP): EndoREZ ${ }^{\circledR}$ sealer was syringed into the canal and then a \#40/0.06 taper GP was placed in the canal up to working length.

After completion of obturation, the coronal access of all specimens was sealed with glass ionomer cement (GC Fuji IX GP; GC Asia), and all 5 groups were stored in an incubator at $37^{\circ} \mathrm{C}$ and $100 \%$ humidity. Each group was further subdivided into 2 subgroups (A and B; 6 in each subgroup) for push-out assessment at 2 weeks and 3 months, respectively.

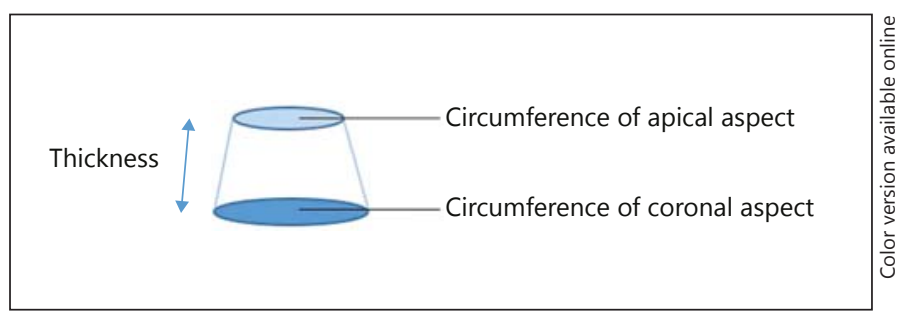

Fig. 2. Diagramatic representation of debonded area.

\section{Push-Out Assessment}

Sixty roots were embedded in a rubber mold individually using epoxy resin (Mirapox; Miracon, Malaysia) (Fig. 1a). After the setting of the mold, the apical $4 \mathrm{~mm}$ of each root was sliced and discarded as the size of the filling material at this level was very small. Subsequently, 3 successive root slices $2 \mathrm{~mm}$ in thickness and a total of 180 root slices were obtained from the remaining portion of each root using a water-cooled precision diamond saw (Micracut 125 low-speed precision cutter; Metkon, Turkey). The thickness of each root slice was verified using a digital caliper (Mitutoyo/Digimatic, Tokyo, Japan). The circumference of the apical and coronal aspect and the diameter of the apical aspect of each slice were measured using a stereomicroscope (Olympus SZ X7; Leica, Tokyo, Japan) at $25 \times$ magnification before subjecting the specimens to the push-out test.

Each specimen was carefully positioned on the jig with the apical surface facing the plunger (Fig. 1b) of a universal testing machine (Shimadzu, Japan) equipped with a $0.6-\mathrm{mm}$-diameter cylindrical stainless steel plunger. To facilitate the correct positioning, a $2.5 \times$ dental surgical loupe $\left(\right.$ EyeMag $^{\circledR}$ Smart; Carl Zeiss Meditec AG, Germany) with light illumination was used. The plunger was in contact with the filling material only to avoid misreading by fracturing the root dentin, thus avoiding inconsistent readings. The parameter for the universal testing machine was the compressive load applied to the filling material at a speed of $0.5 \mathrm{~mm} / \mathrm{min}$ until bond failure occurred.

The bond strength was measured in megapascals $(\mathrm{MPa})$ and calculated by dividing the debonded force $(\mathrm{N})$ over the debonded area of the root canal filling $\left(\mathrm{mm}^{2}\right)$. The debonded area was calcu- 

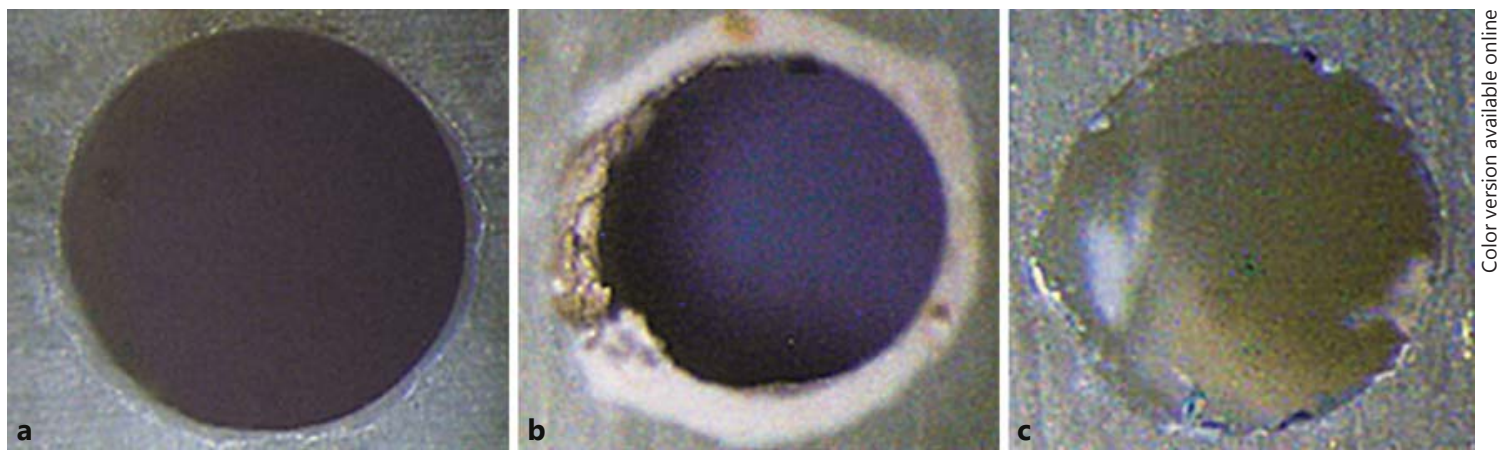

Fig. 3. Stereomicroscopic examination of the samples at $56 \times$ magnification and various failure modes. a Adhesive failure at the dentin-sealer interface. $\mathbf{b}$ Cohesive failure within the filling material. c Mixed failure in both adhesive and cohesive modes.

Table 2. Mean push-out bond strength (MPa) in the experimental groups at 2 weeks and 3 months after obturation

\begin{tabular}{|c|c|c|c|c|}
\hline \multirow[t]{2}{*}{ Groups } & \multicolumn{2}{|c|}{ Bond strength } & \multirow{2}{*}{$\begin{array}{l}p \\
\text { value }\end{array}$} & \multirow{2}{*}{$\begin{array}{l}\text { Mean } \\
\text { difference } \\
(\mathrm{I}-\mathrm{J})\end{array}$} \\
\hline & 2 weeks (I) & 3 months $(\mathrm{J})$ & & \\
\hline G1 & $1.46 \pm 0.29^{\mathrm{a}}$ & $1.70 \pm 1.05^{\mathrm{d}}$ & 0.37 & -0.24 \\
\hline G2 & $1.74 \pm 0.43^{\mathrm{a}}$ & $3.69 \pm 1.20^{c}$ & $<0.001$ & -1.95 \\
\hline G3 & $1.33 \pm 0.29^{\mathrm{a}}$ & $2.84 \pm 0.83^{c}$ & $<0.001$ & -1.51 \\
\hline G4 & $0.66 \pm 0.31^{b}$ & $0.14 \pm 0.05^{\mathrm{e}}$ & $<0.001$ & 0.52 \\
\hline G5 & $0.74 \pm 0.47^{b}$ & $0.24 \pm 0.10^{\mathrm{e}}$ & $<0.001$ & 0.50 \\
\hline
\end{tabular}

Values are mean $\pm \mathrm{SD} . \mathrm{G} 1, \mathrm{AH}$ Plus ${ }^{\circledR} /$ gutta-percha (GP); G2, TotalFill BC obturation system - TotalFill BC sealer/BC-coated GP; G3, TotalFill BC sealer/GP; G4, EndoREZ obturation system -EndoREZ sealer/EndoREZ-coated GP; G5, EndoREZ sealer/ GP. Different superscript letters indicate statistically significant differences among groups $(\mathrm{p}<0.05)$. $\mathrm{a}>\mathrm{b} ; \mathrm{c}>\mathrm{d}>\mathrm{e}$.

lated using the following formula [15]: debonded area $\left(\mathrm{mm}^{2}\right)=$ [circumference of apical aspect $(\mathrm{mm})+$ circumference of coronal aspect $(\mathrm{mm})] / 2 \times$ thickness $(\mathrm{mm})$ (Fig. 2).

\section{Mode of Failure Assessment}

After the push-out test, both sides of the sample including the main cone and sealer plug were examined under stereomicroscope (Olympus SZ X7; Leica) at 56× magnification to determine the mode of failure. The failures were subsequently categorized into (a) adhesive failure at the dentin-sealer interface (Fig. 3a), (b) cohesive failure within the filling material (Fig. 3b), and (c) mixed failure in both adhesive and cohesive modes (Fig. 3c).

\section{Data Analysis}

The Statistical Package for the Social Sciences (SPSS), version 21 (SPSS Inc., Chicago, IL, USA) was used to analyze the data. Repeated measures ANOVA was used to analyze the variance between different filling materials. The significance value was set at $\alpha=0.05$. Multiple post hoc comparisons were selected to reveal the existence of significant differences among the groups. An independent $t$ test $(\alpha=0.05)$ was used to compare the mean pushout bond strength for each group at the 2-week and 3-month intervals.

\section{Results}

The mean values and standard deviations of the pushout bond strength $(\mathrm{MPa})$ at 2 weeks and 3 months after obturation are shown in Table 2 . The difference in the mean values among groups at 2 weeks and 3 months after obturation regardless of location was significant $(p<$ 0.05). The mean push-out bond strengths of G4 and G5 were significantly lower than those of G1, G2, and G3 $(p<0.05)$ at both 2 weeks and 3 months after obturation. However, no statistical difference was detected between G4 and G5.

The G2 and G3 groups showed higher mean push-out bond strength at 3 months $(3.69 \pm 1.20$ and $2.84 \pm 0.83$ $\mathrm{MPa}$, respectively) compared to 2 weeks after obturation $(1.74 \pm 0.43$ and $1.33 \pm 0.29 \mathrm{MPa})(p<0.01)$ (Table 2). For both G4 and G5, the mean push-out bond strength 3 months after obturation $(0.14 \pm 0.05$ and $0.24 \pm 0.10$ $\mathrm{MPa}$, respectively) was significantly lower compared to 2 weeks after obturation $(0.66 \pm 0.31$ and $0.74 \pm 0.47$ $\mathrm{MPa})(p<0.01)$. For G1, no statistically significant difference in mean push-out bond strength was seen at 3 months after obturation compared to 2 weeks after obturation. Stereomicroscopic examination of $180 \mathrm{sam}-$ ples revealed that most of the samples showed mixed failure mode regardless of postobturation interval (Table 3 ).
Push-Out Bond Strength of Different

Sealers to Root Dentin
Med Princ Pract 2017;26:464-469 DOI: $10.1159 / 000481623$ 
Table 3. Failure mode (\%) for each group at 2 weeks and 3 months after obturation

\begin{tabular}{|c|c|c|c|c|c|c|}
\hline \multirow[t]{2}{*}{ Groups } & \multicolumn{3}{|c|}{2 weeks } & \multicolumn{3}{|c|}{3 months } \\
\hline & \multicolumn{3}{|c|}{ adhesive cohesive mixed } & \multicolumn{3}{|c|}{ adhesive cohesive mixed } \\
\hline G1 & 0 & 33.3 & 66.7 & 0 & 38.9 & 61.1 \\
\hline G2 & 0 & 38.9 & 61.1 & 0 & 44.4 & 55.6 \\
\hline G3 & 0 & 61.1 & 38.9 & 5.6 & 50.0 & 44.4 \\
\hline G4 & 0 & 72.2 & 27.8 & 0 & 55.6 & 44.4 \\
\hline G5 & 16.7 & 22.2 & 61.1 & 5.6 & 22.2 & 72.2 \\
\hline
\end{tabular}

G1, AH Plus ${ }^{\circledR} /$ gutta-percha (GP); G2, TotalFill BC obturation system - TotalFill BC sealer/BC-coated GP; G3, TotalFill BC sealer/GP; G4, EndoREZ obturation system - EndoREZ sealer/EndoREZ-coated GP; G5, EndoREZ sealer/GP.

\section{Discussion}

In the current study, both TotalFill $\mathrm{BC}^{\mathrm{TM}}$ obturation systems performed equally in push-out bond strength compared to $\mathrm{AH}$ Plus ${ }^{\circledR}$ at 2 weeks after obturation, and the bond strengths showed an increase at 3 months after obturation. This could be attributed to the high flowability of the $\mathrm{BC}$ sealer [16] which leads to deeper penetration of the sealer into the dentinal tubules for micromechanical interlocking, thus resulting in greater adhesion. Moreover, incorporated calcium phosphates in the sealer facilitate a reaction with calcium hydroxide upon activation by the moisture that remains within the dentinal tubules, producing hydroxyapatite. Hydroxyapatite is coprecipitated within the calcium silicate hydrate phase [17] to produce a composite-like structure, reinforcing the set cement [18].

In this study, the bond strength of TotalFill $\mathrm{BC}^{\mathrm{TM}}$ was comparable to AH Plus ${ }^{\circledR} / \mathrm{GP}$ and higher than EndoREZ ${ }^{\circledR}$ at 2 weeks, and this is consistent with a previous study [10]. Also, the push-out bond strength increased significantly over time from 2 weeks to 3 months after obturation for G2 (BC sealer/BC-coated GP) and G3 (BC sealer/ GP). G1 (AH Plus $\left.{ }^{\circledR} / G P\right)$ showed an increase in bond strength with time, but this was statistically not significant. This result is similar to that of a study by Elbatouty et al. [19], where the push-out bond strength of a bioceramic sealer was compared to AH Plus ${ }^{\circledR}$ and eugenolbased sealer KERR EWT at 1 week, 2 weeks, and 1 month. Their results showed an increasing trend of bond strength from 1 week to 1 month for both TotalFill $\mathrm{BC}^{\mathrm{TM}}$ and $\mathrm{AH}$ Plus ${ }^{\circledR}$. This finding may be attributed to the increased setting and hardening of the material over time.

In the current study, G4 (EndoREZ ${ }^{\circledR}$ sealer/EndoREZ ${ }^{\circledR}$ coated GP) and G5 (EndoREZ ${ }^{\circledR}$ sealer/GP) had signifi- cantly lower bond strengths regardless of the time interval. A probable explanation could be the high c-factor ( $\mathrm{ra}$ tio of bonded to unbounded resin surfaces) seen in root canals, which concentrates high polymerization stresses between resin-based materials and the canal walls; these stresses may exceed the bond strength of adhesives to dentin, resulting in gap formation along the surfaces [20]. This finding confirmed those of previous studies [9-11, 21] which showed that EndoREZ ${ }^{\circledR}$ has low push-out bond strength. The push-out bond strength of G4 and G5 decreased further at 3 months compared to 2 weeks after obturation and remained the lowest in bond strength among all groups. A possible explanation for this could be the percolation of fluid through the gaps along the surface, which in turn leads to plasticization and hydrolysis of the resin [22]. In addition, collagen degradation may occur due to host-derived matrix metalloproteinases in dentin that are slowly released over time when self-etching adhesives are used. During push-out testing, the specimen should be positioned vertically, with a plunger size slightly smaller than the canal diameter to minimize interfacial sliding friction [23]. The diameter of the apical side of each slice was measured and a push-out plunger of $0.6 \mathrm{~mm}$ was chosen as it was within the range of $70-90 \%$ of canal diameter. A plunger size $70-90 \%$ of the canal diameter has been shown not to affect the bond strength [24].

\section{Conclusions}

In this study, the TotalFill $\mathrm{BC}^{\mathrm{TM}}$ obturation system (G2) and the TotalFill BC ${ }^{\mathrm{TM}}$ sealer (G3) showed comparable bond strengths to AH Plus ${ }^{\circledR}$. The bond strength also exhibited an increase over a 3-month postobturation period. On the other hand, the EndoREZ ${ }^{\circledR}$ obturation system (G4)/EndoREZ ${ }^{\circledR}$ sealer (G5) had significantly low push-out bond strengths which decreased over the same period. Thus, the push-out bond strength of the sealer to intraradicular dentin is influenced by the time after obturation and also the composition of the sealer.

\section{Acknowledgment}

This study was supported by the University of Malaya (grant No. PPPC/C1-2015/DGI/06).

\section{Disclosure Statement}

The authors have no conflicts of interest to declare.
468

Med Princ Pract 2017;26:464-469

DOI: $10.1159 / 000481623$
Yap/Che Ab Aziz/Azami/Al-Haddad/

Khan 


\section{References}

1 Ng YL, Mann V, Rahbaran S, et al: Outcome of primary root canal treatment: systematic review of the literature. Part 2. Influence of clinical factors. Int Endod J 2008;41:6-31.

2 Grossman LI: Physical properties of root canal cements. J Endod 1976;2:166-175.

3 Ørstavik D, Eriksen H, Beyer-Olsen EM: Adhesive properties and leakage of root canal sealers in vitro. Int Endod J 1983;16:59-63.

4 Stewart GG: A comparative study of three root canal sealing agents. Oral Surg Oral Med Oral Pathol 1958;11:1029-1041.

5 Tay FR, Pashley DH: Monoblocks in root canals: a hypothetical or a tangible goal. J Endod 2007;33:391-398.

6 Zmener O, Pameijer CH, Serrano SA, et al: Significance of moist root canal dentin with the use of methacrylate-based endodontic sealers: an in vitro coronal dye leakage study. J Endod 2008;34:76-79.

7 Taşdemir T, Er K, Çelik D, et al: Bond strength of calcium silicate-based sealers to dentine dried with different techniques. Med Princ Pract 2014;23:373-376.

8 Ungor M, Onay EO, Orucoglu H: Push-out bond strengths: the Epiphany-Resilon endodontic obturation system compared with different pairings of Epiphany, Resilon, $\mathrm{AH}$ Plus and gutta-percha. Int Endod J 2006;39: 643-647.

9 Fisher MA, Berzins DW, Bahcall JK: An in vitro comparison of bond strength of various obturation materials to root canal dentin using a push-out test design. J Endod 2007;33: 856-858.
10 Ersahan S, Aydin C: Dislocation resistance of iRoot SP, a calcium silicate-based sealer, from radicular dentine. J Endod 2010;36:20002002.

11 Sanjana Patil A, Preeti Dodwad K, Avinash Patil A: An in vitro comparison of bond strengths of Gutta-percha/AH Plus, Resilon/ Epiphany self-etch and EndoREZ obturation system to intraradicular dentin using a pushout test design. J Conserv Dent 2013;16:238242 .

12 Goracci C, Tavares AU, Fabianelli A, et al: The adhesion between fiber posts and root canal walls: comparison between microtensile and push-out bond strength measurements. Eur J Oral Sci 2004;112:353-361.

13 Soares CJ, Santana FR, Castro CG, et al: Finite element analysis and bond strength of a glass post to intraradicular dentin: comparison between microtensile and push-out tests. Dent Mater 2008;24:1405-1411.

14 De Munck J, Van Landuyt K, Peumans M, et al: A critical review of the durability of adhesion to tooth tissue: methods and results. J Dent Res 2005;84:118-132.

15 Sly MM, Moore BK, Platt JA, et al: Push-out bond strength of a new endodontic obturation system (Resilon/Epiphany). J Endod 2007;33:160-162.

16 Candeiro GT, Correia FC, Duarte MA, et al: Basic research: evaluation of radiopacity, $\mathrm{pH}$, release of calcium ions, and flow of a bioceramic root canal sealer. J Endod 2012;38: 842-845.
17 Majeed A, AlShwaimi E: Push-out bond strength and surface microhardness of calcium silicate-based biomaterials: an in vitro study. Med Princ Pract 2017;26:139-145.

18 Loushine BA, Bryan TE, Looney SW, et al: Setting properties and cytotoxicity evaluation of a premixed bioceramic root canal sealer. J Endod 2011;37:673-677.

19 Elbatouty KM, Ibrahim DY, Youniss WN: In vitro bond strength of bioceramic root canal sealer in comparison to resin-based and eugenol-based root canal sealers. ENDO 2015;9: 59.

20 Carvalho, Pereira JC, Yoshiyama M, et al: A review of polymerization contraction: the influence of stress development versus stress relief. Oper Dent 1995;21:17-24.

21 Mahdi AA, Bolanos-Carmona V, GonzalezLopez S: Bond strength to root dentin and fluid filtration test of AH Plus/gutta-percha, EndoREZ and RealSeal systems. J Appl Oral Sci 2013;21:369-375.

22 Souza Sde F, Francci C, Bombana AC, et al: Qualitative SEM/EDS analysis of microleakage and apical gap formation of adhesive rootfilling materials. J Appl Oral Sci 2012;20:329334.

23 Castellan CS, Santos-Filho P, Soares PV, et al: Measuring bond strength between fiber post and root dentin: a comparison of different tests. J Adhes Dent 2010;12:477-485.

24 Pane ES, Palamara JE, Messer HH: Critical evaluation of the push-out test for root canal filling materials. J Endod 2013;39:669-673.
Push-Out Bond Strength of Different Sealers to Root Dentin
Med Princ Pract 2017;26:464-469

DOI: $10.1159 / 000481623$ 